\title{
Nigerian Migrants' Remittances: The Unofficial Channel
}

\author{
Abiola A. Martins \\ International Graduate Center, Hochschule Bremen
}

This research was self-funded.

\begin{abstract}
The official remittance to Nigeria is reducing while the Central Bank of Nigeria (CBN) grapples with the situation. A survey of about 200 students in a German city showed that most of them remit money via peer-to-peer services. This system is based on mutual trust and costless and reliable service. The survey was designed based on the sociodemographic profile of migrants from previous studies. The article uncovered the amounts being remitted and laid the groundwork for a comprehensive future and wider research.
\end{abstract}

Keywords: Migrants, migration, Nigeria, remittance, students, US\$.

DOI: $10.7176 / \mathrm{EJBM} / 13-23-05$

Publication date: December $31^{\text {st }} 2021$

\section{Introduction}

Migration is a complex event having multiple correlations with human development. It increases employment opportunities and expands the social viewpoints of both migrants and natives. Conversely, migration also creates opportunities for exploitation and abuse of migrants (Khanal \& Todorova, 2021). International development discourse and practices have moved from migration driven by poverty to poverty reduction and development through remittances (World Bank, 2006; Sunam \& McCarthy, 2016). Remittance is a vital income source for developing nations, making it an important subject and research area.

The objectives of this article may be summarised as follows:

1. To investigate the remittance practices of the Nigerian students in a German city.

2. To develop a model for estimating the total amounts remitted.

3. To investigate the reasons for the remittances.

4. To lay the foundation for the estimation of the global Nigerian unofficial remittances.

Remittances refer to the money migrants send to their home countries, the second most important source of foreign finance for developing countries (Ambrosius \& Cuecuecha, 2016). Remittances are financial or in-kind transfers made by migrants to family and friends back in their countries of origin. They are the most precise and eminent link between migration and development (capital and technology transfer).

Between 1990 and 2020, migrants increased from 153 to 280.6 million (UN, 2021). These correspond to $2.87 \%$ and $3.6 \%$ of the then world's population respectively. Approximately $0.024 \%$ of the global population migrates annually. According to the UN (2021), the US has the highest number of migrants (50.6 million), followed by Germany (15.8 million) and Saudi Arabia (13.5 million). High-income countries are the key source of remittances (Azizi, 2018). The top 5 sender countries are the USA (US\$68 billion), the United Arab Emirates (US\$43 billion), Saudi Arabia (US\$35 billion), Switzerland, and Germany (World Bank, 2018; Mintchev \& Boshnakov, 2021). The top recipient countries in 2020 are India (US\$83 billion), China (US\$60 billion), Mexico (US\$43 billion), the Philippines (US\$35 billion), Egypt (US\$30 billion), and Nigeria (US\$17 billion) in the tenth place (Mintchev \& Boshnakov, 2021; Statista, 2021).

The total amount of global remittance inflows rose from US\$36 billion in 1980 to an estimated US\$702 billion in 2020 (World Bank, 2021), of which US\$540 billion was officially remitted to the low and middle-income countries (LMIC). Official remittances to developing countries quadrupled from US\$85 billion in 2000 to US\$372 billion in 2011 (World Bank, 2011) and sextupled to US\$540 billion in 2020. Unofficial remittances are a major obstacle to sound and efficient financial policies (Azizi, 2014). The amounts remitted via unofficial channels remain unknown and are assumed to be significant.

The rest of the paper proceeds as follows. A literature review and the Nigerian perspective. The adopted methodology, vis-a-vis an empirical strategy. Then a data section to present the findings and a conclusion section to interpret the findings.

\section{Literature Review}

Each migrant from developed and developing countries remitted US\$3,533 and US\$2,603 respectively to their home countries in 2014 (Azizi, 2018). The motivations behind these remittances depended on the reasons for sending them. These motives include altruism, investments, and loan repayments. Migrants often borrow from their families/ friends to cover the cost of migration (education for access to better-paying jobs in the developed countries). Then the migrants send back remittances from these better-paying jobs to offset the loans taken from family members (Hagen-Zanker \& Siegel, 2007 as cited in Azizi, 2018). 
Migrants from rich countries typically go to rich countries, earn quite large sums of money and remit more to their home countries (Azizi, 2014). Migrants from poor countries often face visa and work permit difficulties in rich countries. This affects how much they are able to remit back home and reasons for remittance. Understanding the reasons for remittance is very important for policymaking (Azizi, 2014). These reasons are also important to money intermediaries (Western Union, MoneyGram, banks, etc.). Knowing exactly how remittances respond to different economic variables informs these intermediaries' decisions better.

Altruism appears to be more important to migrants from developing countries than those from developed countries. Researchers use two general methodologies to determine the motivations for remittances, micro-level (individual-level) data or macro-level (country-level) data (Azizi, 2014). The main advantage of the micro-level methodology is the availability of migrants' data (age, gender, education level, income, years of living abroad, and the number of family members living abroad, etc.). This makes it possible to include and control specific characteristics in the regression model.

However, micro-level data are typically available for a limited number of migrants; often migrants from one village or city or from two countries at most. Such data produces a wide range of results, which could be contradictory, thus, not generalizable. The macro-level methodology does not include individual demographic characteristics, though comprehensive datasets of nearly all countries for a very long period are always available. This is because the IMF requires the central banks of all member countries to prepare their balance of payments. It is almost impossible for central banks to track the source countries of all remittances. While the total inflow of remittances via official channels is normally known, the percentage of the remittances from each specific sending country is mostly unknown. Azizi (2014) used estimated data on bilateral remittances to overcome this challenge.

According to Batistaa and Umblijs (2015), the reasons behind remittances vary from altruism, selfish or reciprocal motives to social pressure. Migrants also self-insure against unexpected negative shock(s) in their host countries (purchase of future goods and services for their own use in specific states of nature). Using a tailored representative household survey of the Greater Dublin Area's migrant population (including illegal and unregistered migrants), they surveyed 1,354 migrants ( $\geq 18$ years), to determine reasons behind individual remittances.

Their results were consistent with the existing literature, a (weak) negative relationship between income and risk aversion. Students were very strongly negatively correlated with risk aversion. The marital status of migrants seemed to be strongly correlated with risk aversion. Migrants living with their partners in the host country were significantly more risk-averse, though partners having identical nationalities are associated with lower risk aversion. Migrants who remitted to non-family members were particularly more risk-averse. The results showed a positive correlation between risk aversion and remittances.

Having control for individual key characteristics makes this measure a good proxy for the inherent risk preference of individuals in the domain of money. This type of risk measure was validated using real monetary motivations for the German Socioeconomic Panel study by Dohmen et al. (2011). The study proved that this hypothetical question is able to depict the genuine risk attitudes in the domain of money of the respondents in the survey. Although migrants who intend to return to their home countries are likelier to benefit from the support of network members after return, the research found no strong significant relationship between the intention to return and remittances in general.

Batistaa and Umblijs (2015) posited that risk-averse respondents intending to return back home have a higher motivation to remit for self-insurance purposes. Risk-loving migrants are unlikely to remit if their network members are employed, while risk-averse migrants are likely to remit if network members are employed. This validated the hypothesis that risk-averse migrants are inclined towards insurance, hence, they remit more should their networks be gainfully employed. So, risk-loving individuals are less inclined towards self-insurance and remit for other motives such as altruism. This creates a negative correlation between the finances of their network and remittances. Individual risk aversion variables allowed the examination of self-insurance remittance motive in a new way and their hypothesis was supported in previous literature. It is a vital indicative discovery for policymakers since remittances to developing countries, in particular, keep growing.

Remittances are linked to the existence of debts, recent borrowing, the existence of savings, and the ownership of savings accounts in home countries (Ambrosius \& Cuecuecha (2016). Their Mexican household data and some previous studies show an effect of remittances on savings accounts and deposits. There is a causal effect of remittances on borrowing from informal sources. This indicates that certain remittance receivers provide a financial service to intending migrants, including loans before they migrate and savings options afterward. Informal financial channels readily lend against remittances, but the formal institutions and traditional banks are unresponsive to the financial demands of remittances senders and receivers outside the provision of savings accounts.

\subsection{Data and Demography}

Batistaa and Umblijs' (2015) respondents were 51\% female, 49\% male. Their average age was 33 years and each 
had about 15 years of schooling. $40 \%$ of them were married or in stable relationships, and $45 \%$ had children. $31 \%$ were married or in a stable relationship with their compatriots, and only $4 \%$ to an Irish partner. Their average monthly net income was $€ 1,162$, and about $25 \%$ had a temporary work contract. $20 \%$ of them were students, $12 \%$ worked in the health sector, $11 \%$ in ICT and about $9 \%$ were unemployed. They had lived in Ireland for an average of 7 years. $53 \%$ wished to eventually return to their home country.

$36 \%$ of the migrants in the survey sent money back home at least once in the year preceding the interview. Less than $12 \%$ reported having any savings in Ireland. Amounts sent back home varied significantly, ranging between $€ 3$ and $€ 10,000$. The main remittance recipients were not family members according to $34 \%$ of respondents ( $61 \%$ of whom were fully employed at the time). There was ample variation in the probability of remitting across the different world regions of birth. Migrants from Africa ( $40 \%$ sending some money home) were the likeliest to remit, followed by Asians (36\%). 31\% of the EU's new member state migrants remit and only 7\% of pre-2004 enlargement EU states remit any money.

\subsection{Remittances to Nigeria}

Figure 1. Nigerian migrants in figures.

\section{International migrants as a percentage of the total population in Nigeria in selected years from 1990 to 2020}

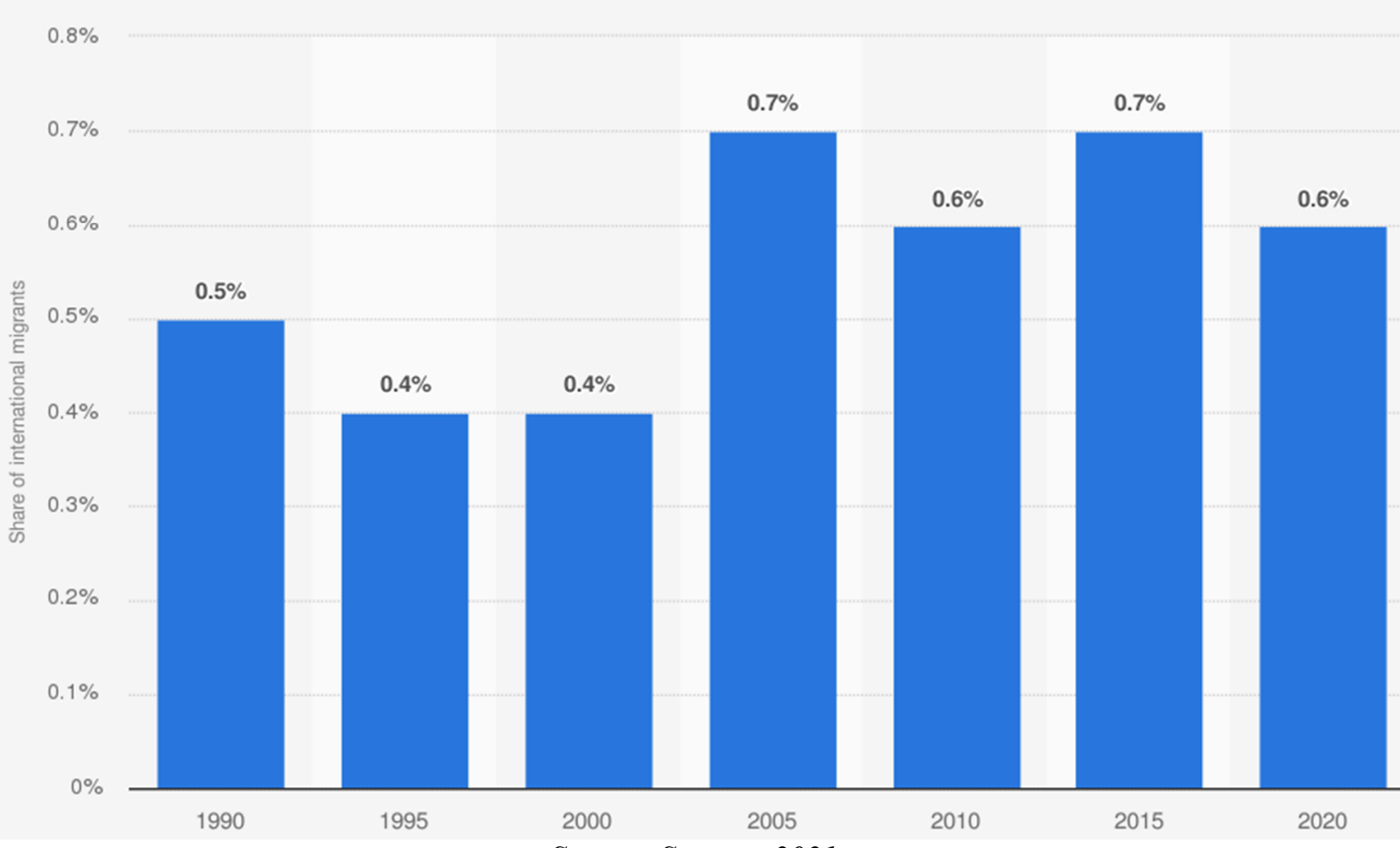

Source: Statista, 2021.

Nigeria currently has an estimated population of 212.5 million people (Varrella, 2021; Statista, 2021). Figure 1 shows the percentage of Nigerians living abroad since 1990 till date. From 1990 till date, an average of $0.55 \%$ of Nigerians live abroad. Today about $0.6 \%$ (1.28 million) of Nigerians live abroad, this is lower than the $0.7 \%$ in 2015. The $0.1 \%$ reduction between 2005 to 2010 and 2015 to 2020 caused the 2008 global recession and 2019 Covid-19 pandemic respectively. 
Figure 2. Remittances to Nigeria.

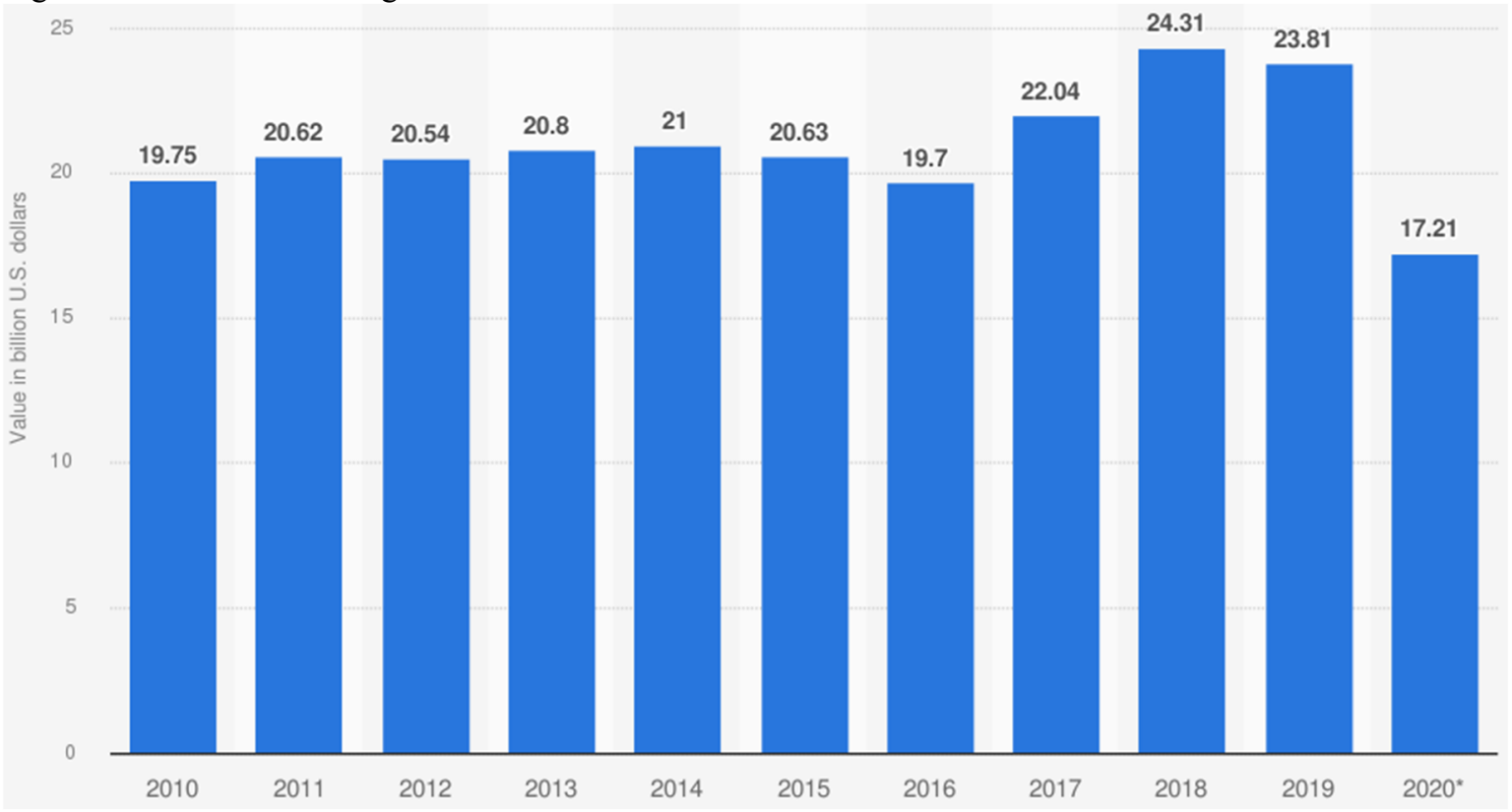

Source: World Bank, 2021.

Figure 3a: Top recipients of remittances, 2019.

\section{( $\$$ billion, 2019e)}

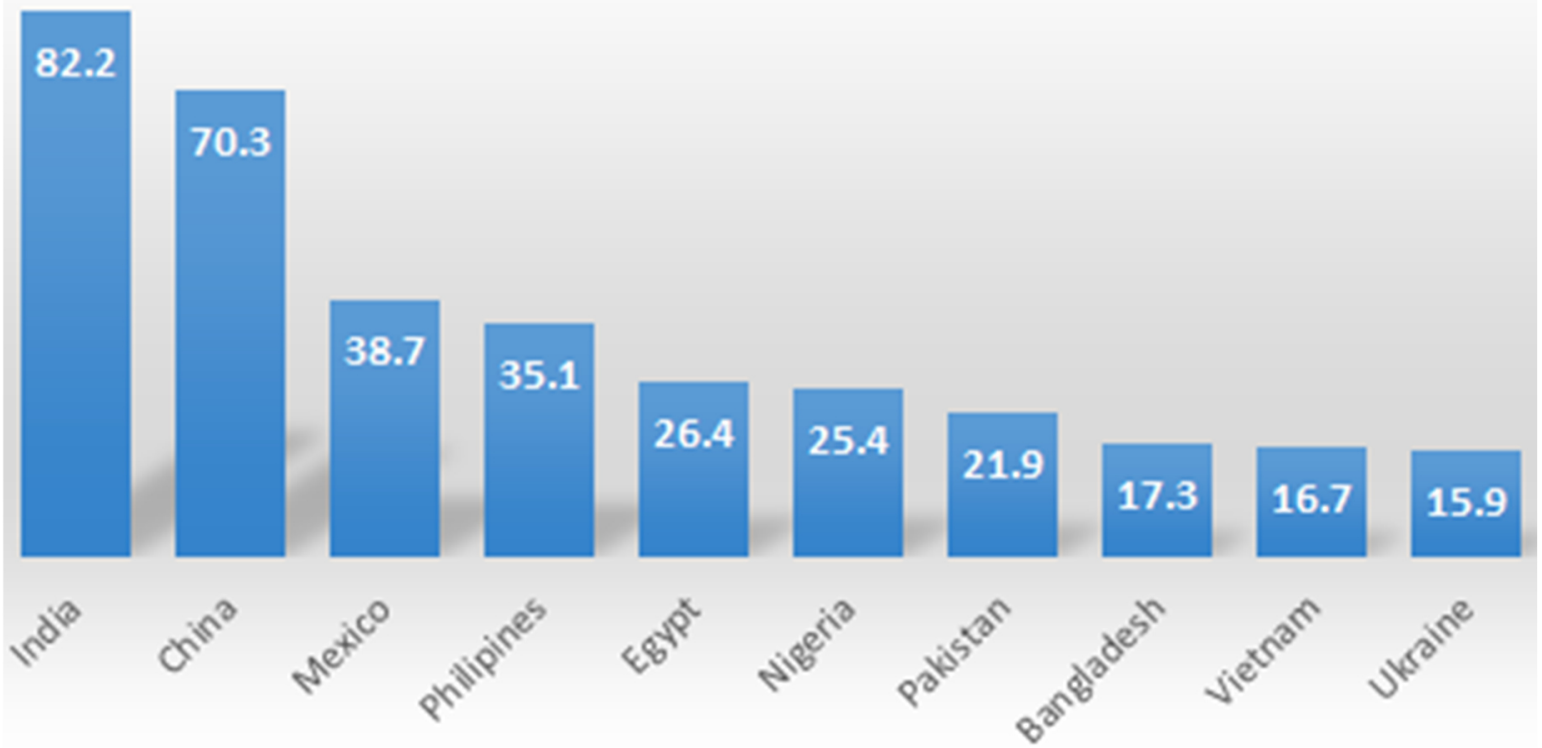

Source: World Bank-KNOMAD, 2021.

According to Onu (2020), Nigerian migrants remit more than reported figures, by bypassing official channels. He asserted that multiple exchange rates and the CBN's poor policies (to protect the Naira) amidst lower oil prices and plummeting foreign investments. "When you have such divergent foreign-exchange rates, many expats will find ways to get money into Nigeria at the best possible rate," (Charlie Robertson, 2019 as cited by Onu, 2020). Thus, official channels are rising because migrants want more Naira for their foreign currencies.

Figures $3 \mathrm{a}$ and $3 \mathrm{~b}$ show the top remittance-receiving countries in the world. Nigeria was sixth in 2019 and tenth in 2020. Nigerian remittances were reduced by US $\$ 8.2$ billion $(0.33 \%)$ between both years. This is mostly attributed to the Covid-19 pandemic. However, there is an assumption that the use of unofficial channels might have reduced the remittances also. 
Figure 3b: Top recipients of remittances, 2020.

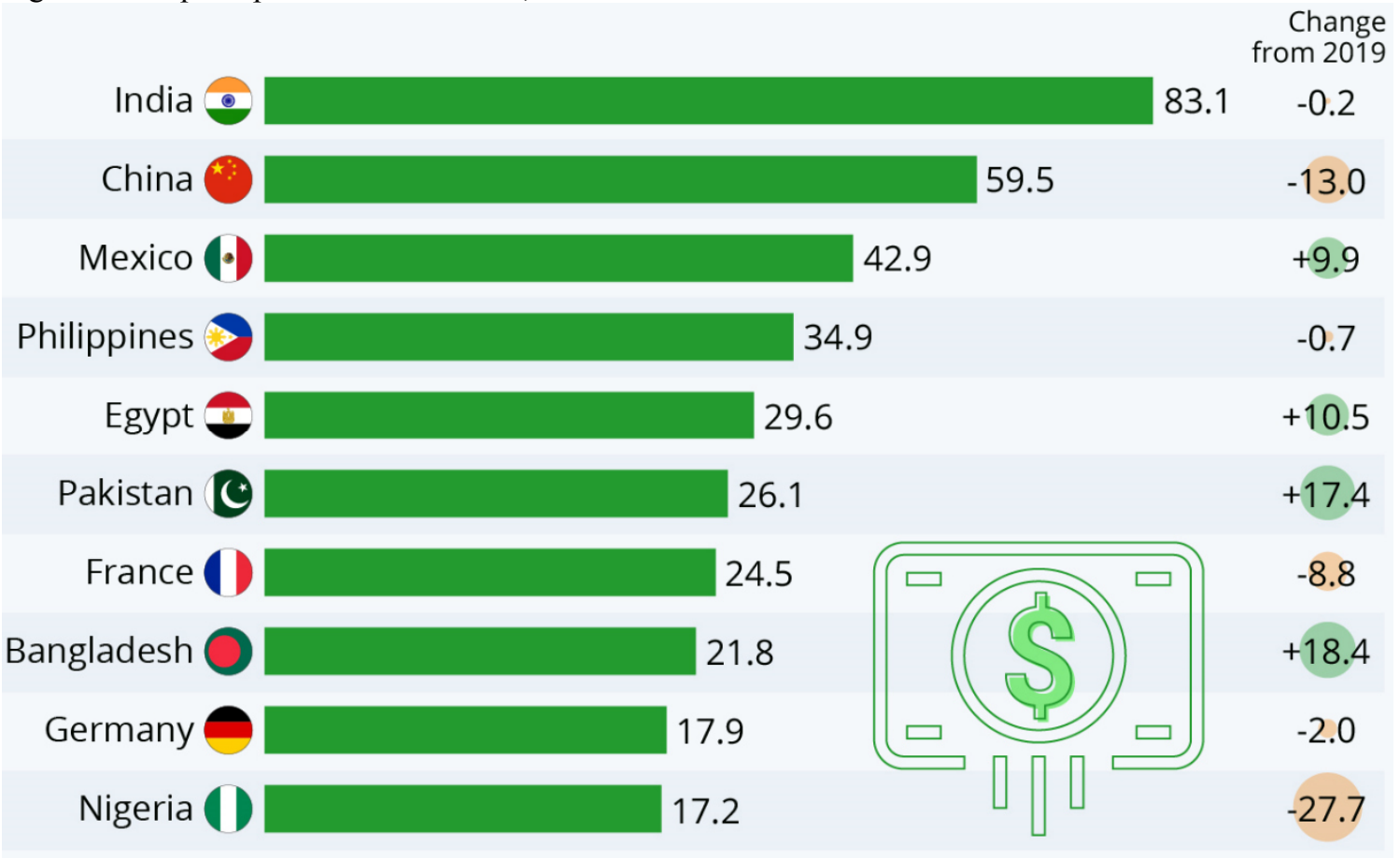

Source: World Bank-KNOMAD, 2021.

Figure 4: Remittances on track to overtake FDI flows.

\section{(a) Global flows including China}

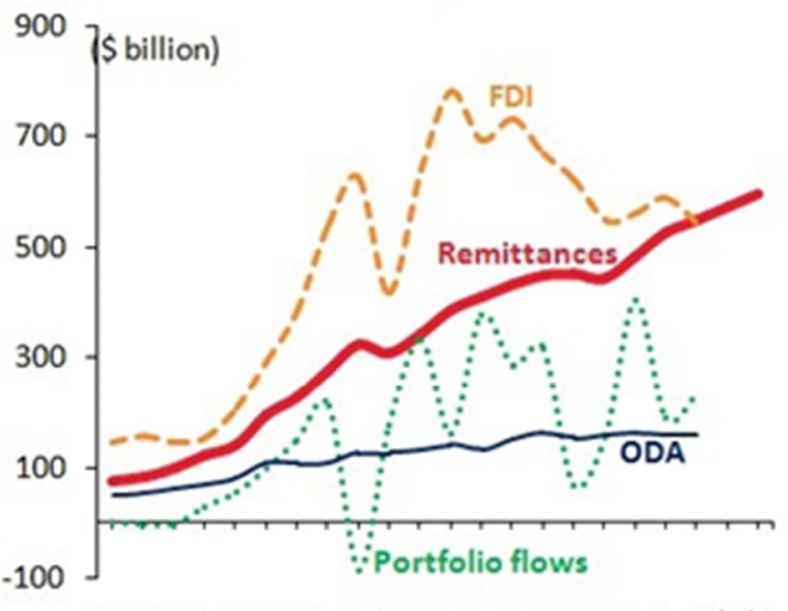

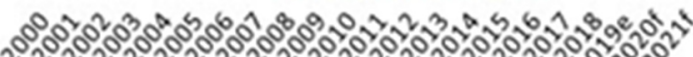

(b) Global flows excluding China

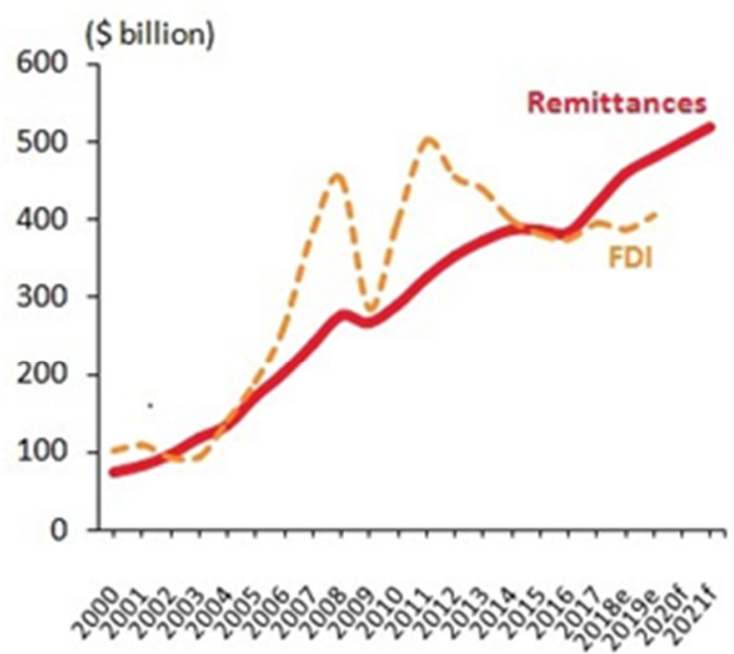

Sources: World Bank-KNOMAD staff estimates, World Development Indicators, and

International Monetary Fund (IMF) Balance of Payments Statistics.

Note: $F D I=$ foreign direct investment $; O D A=$ official development assistance.

Figure 4 shows that remittances are on track to overtake FDI. If the total remittances to Nigeria remain unknown, the government and other financial stakeholders would be making decisions based on inaccurate data. FDIs have been on a continuous decline since 2011. Nigeria's major source of foreign revenue is crude oil, however, advancements in green energy threaten the future revenues from crude oil. Should remittances become the highest source of foreign revenue, knowing the actual figures will be vital for sound fiscal policies.

Figure 5 shows that $12 \%$ of remittances to Nigeria are from the Eurozone. Germany offers tuition-free universities which are very attractive to all migrants, including Nigerians. That is why Germany is a good source of data to study remittances to Nigeria. 
Figure 5: Sources of remittance to low and middle-income countries (LMICs) by currency

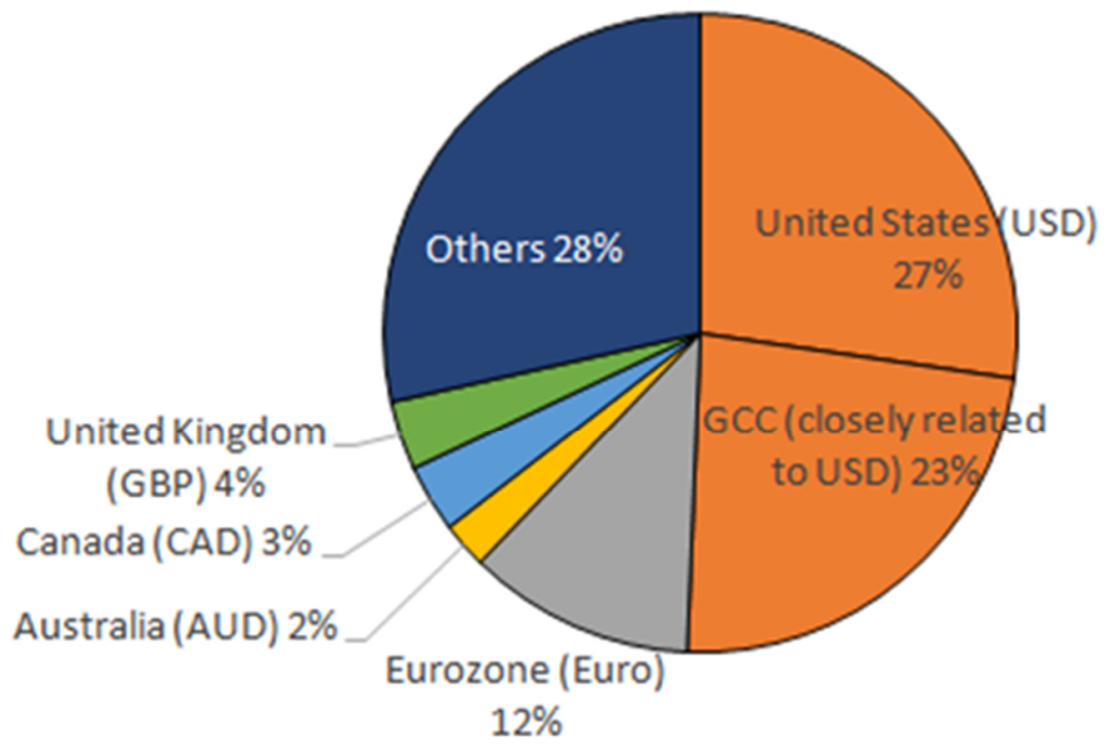

Sources: World Bank-KNOMAD staffestimates. Note: $A U D=$ Australian dollar; $C A D=$ Canadian dollar; $G B P=$ British Pound, USD $=$ US dollar

2.3 Why do migrants remit via unofficial channels?

Figure 6: Exchange Rate: Dollar to Naira.

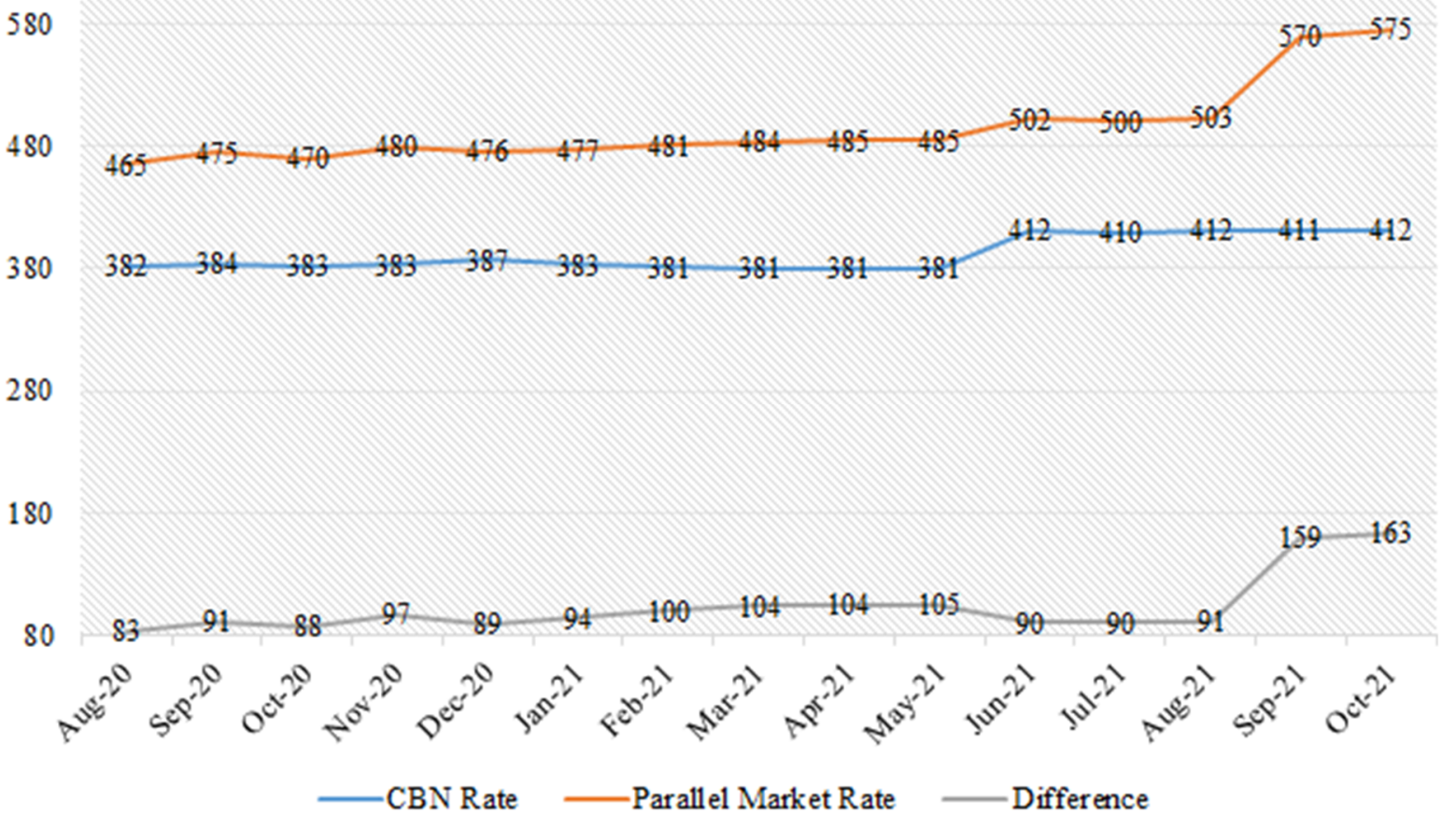

Source: Bloomberg, abokifx.com.

The IMF and World Bank do not have any data on unofficial remittances. They only have evidence that it occurs significantly. The following may be assumed as reasons:

1. The multiple exchange rates in Nigeria.

2. The high cost of remittances.

3. Owning saving accounts back home.

Figure 6 shows the average exchange rate of the Dollar to Naira in the last year. The CBN pegged the exchange rate of $\$ 1$ to an average of $\$ 392$, while the parallel market averaged $\$ 493$ to $\$ 1$. This means migrants would get about 103 more from the black market, 21\% more than the CBN's rate. Though the Dollar is the most traded currency in Nigeria, multiple exchange rates also apply to the Euro and others. $21 \%$ is incentive enough for migrants to exchange their foreign currencies in the parallel market. There are two ways to avoid official channels; 
either by transferring the foreign currency to a parallel market dealer directly (to an account domiciled outside Nigeria) or using a peer-to-peer service.

Figure 7: Cost of Sending US\$200.

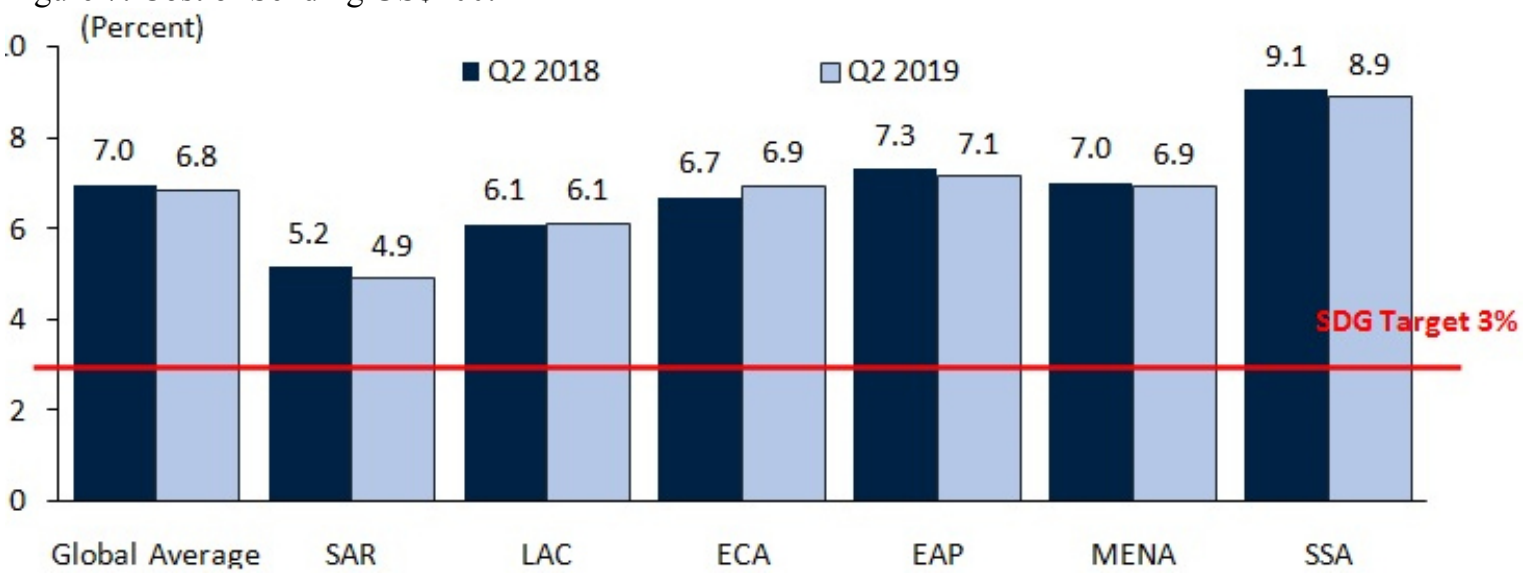

Source: Remittance Prices Worldwide database, World Bank.

Note: $E A P=$ East Asia and Pacific; ECA = Europe and Central Asia; LAC = Latin America and the Caribbean; MENA = Middle East and North Africa; SAR = South Asia; SSA = Sub-Saharan Africa.

Figure 7 shows the World Bank's Remittance Prices Worldwide Database. The average cost of sending US\$200 to LMICs was $6.8 \%$ in the second quarter of 2019, just marginally below the previous quarters. This is $225 \%$ of the Sustainable Development Goal (SDG) target of $3 \%$ by 2030 . South Asia had the lowest cost at $5 \%$, while Sub-Saharan Africa was the highest at 9\%. Many African corridors and small islands in the Pacific cost over $10 \%$. Intra-regional migration in Africa accounts for over two-thirds of all international migration from Africa. Previous studies indicate very high costs for sending money within Africa (Leveraging Migration for Africa, World Bank, 2011), this encourages the use of unofficial channels.

Figure 8: Average costs of remittances from different providers, 2019 Q2.

(Percent)

10.3

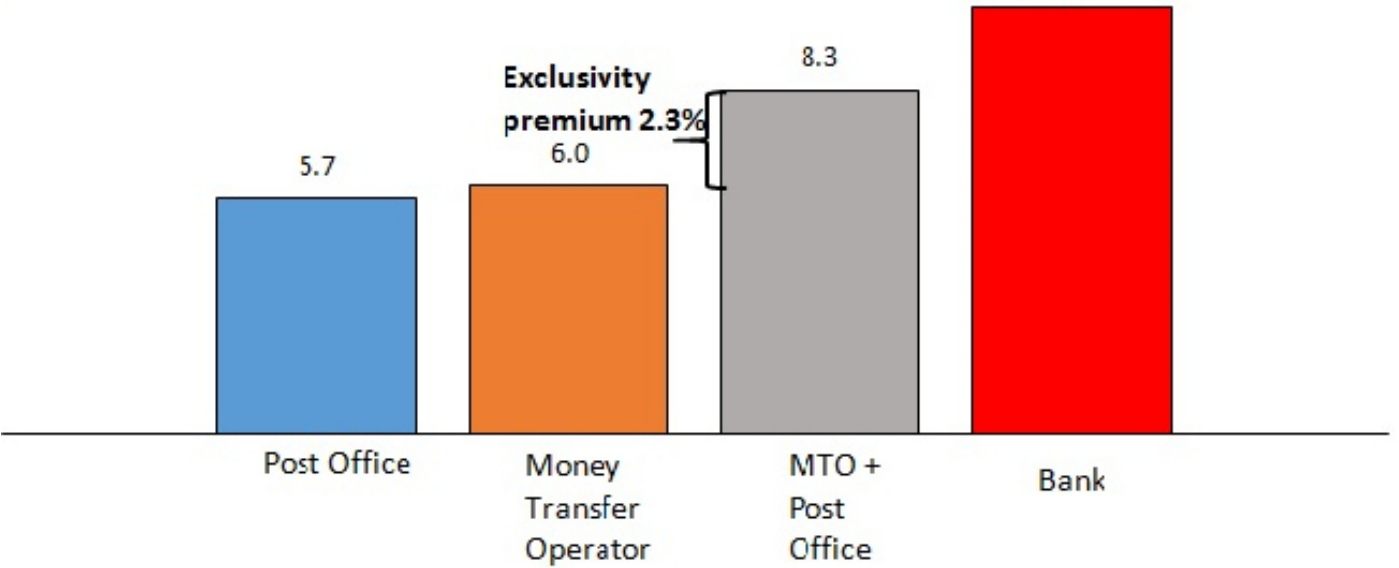

Source: Calculations by World Bank-KNOMAD staff for 2018 Q4 based on the Remittance Prices Worldwide database, World Bank. Note: MTO = money transfer operator.

Figure 8 shows that banks are the most expensive channel for remitting, averaging $10.3 \%$ in 2019 Q2, while post offices averaged $5.7 \%$. Remittance costs are wont to include a premium, a cost mark-up in exclusive partnerships between national post offices and dominant money transfer operator (MTO). These premiums average $2.3 \%$ of the cost of remitting worldwide and rise as high as $4.6 \%$ in India (largest remittances receiver). Promoting partnerships between national post offices, national banks, and telecommunications companies, and MTOs could increase competition in remittance markets and crash costs.

Figure 9 shows that cash transfers at 7\% remain the most expensive means of remittance, followed by banks at $6.6 \%$, credit/debit cards at $4.82 \%$, and mobile money at $4.4 \%$. However, mobile money remains mostly local (between local operators) in Nigeria. Thus, Nigerian migrants can only access other expensive (official) means to remit. Furthermore, regulations regarding anti-money laundering and countering the financing of terrorism (AML/CFT) tend to be arduous with respect to cash remittances by unbanked migrants and their families back home (Ratha et al., 2019). Compliance is easier when remittances originate from bank accounts. There has been a quick increase in mobile-phone and internet-based financial solutions for remittance services, and more recently, 
in blockchain-based applications. However, these fintech solutions almost exclusively depend on banks to provide the know-your-client compliance requirements. This leaves out many unbanked customers.

Figure 9: Average costs of global remittances.

\section{Average costs of remittances worldwide from 2016 to 2020, by payment type}

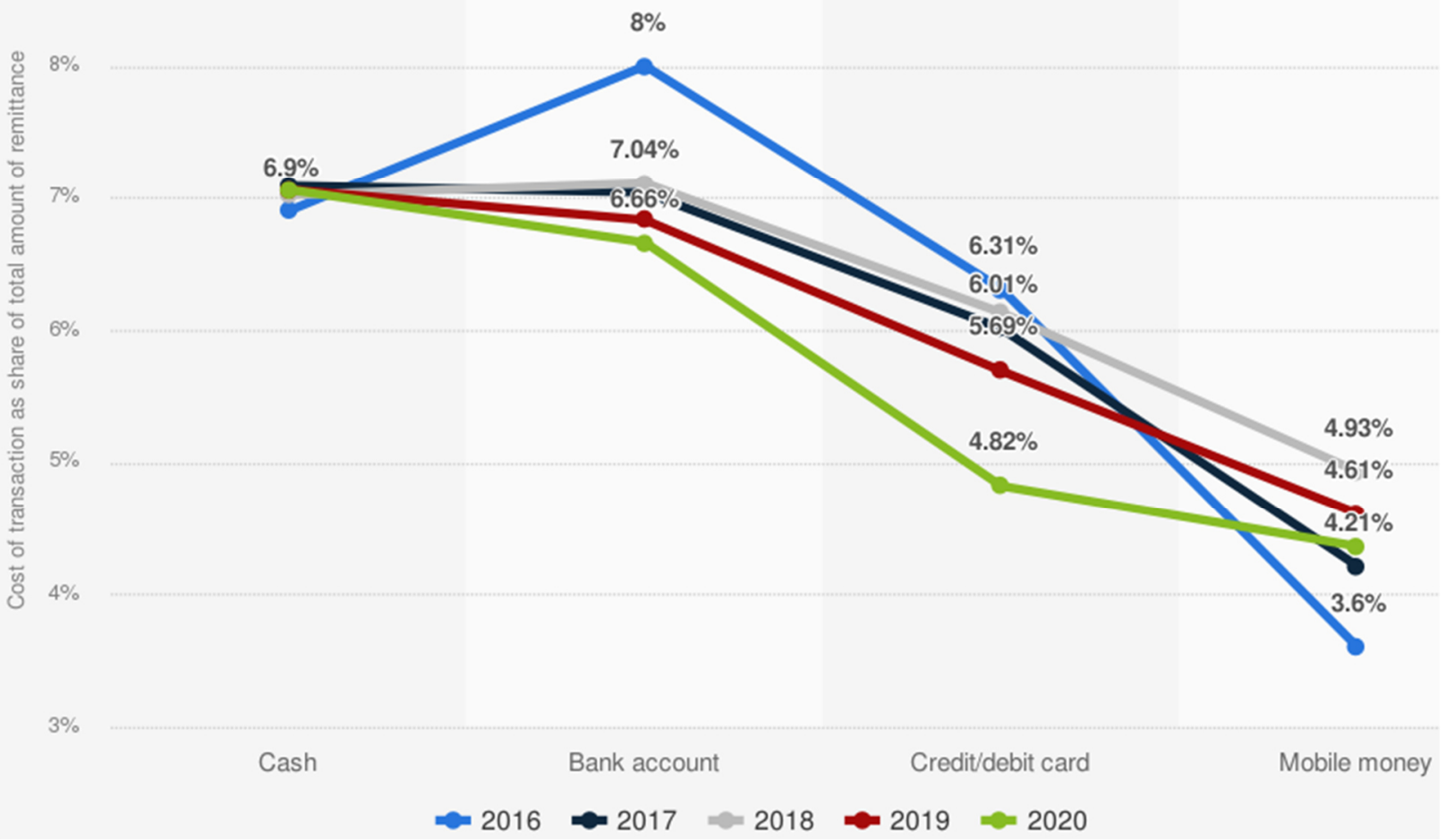

Source: World Bank, 2021.

\subsection{The Future of Remittances}

According to Ratha et al. (2019), should outward remittances grow in tandem with the nominal GDP (in US\$) of the source countries, remittances could reach record amounts. However, Covid-19 negatively impacted the forecast. The methodology was conservative and made no provision for increasing migration flows, cheaper remittance costs, and better remittance services. Conversely, there are factors against this forecast, mainly the antiimmigration sentiment in virtually all large host countries (the United States, Europe, Russia, and South Africa). The Gulf Cooperation Council (GCC) countries, whose economies critically depend on migrant labour, aim to pursue anti-migrant policies. By employing more citizens, enforcing taxes, and constraining remittances.

Meanwhile, the World Bank predicts continuous restraint against the growth of remittances. This is due to the high service charges and severe financial regulations. It expects global migration to increase significantly in a decade, owing to the following basic drivers of migration. The average income disparity between high-income and low-income countries is 54:1 (over US\$43,000 to under US\$800). Demographical change is another driver. By 2030, LMICs would have an additional 550 million workers. Unemployment would increase migration exponentially. The World Bank's 2018 Groundswell report estimates that 143 million people could be displaced due to climate change. Moreover, migration and refugee movements could increase due to fragility, conflict, and violence in unstable West African countries including Nigeria.

\section{Methodology}

Scientific research needs continuous methodology improvement and theory validation processes (Ioannidis et al., 2015). A survey was designed to obtain the required data from the respondents. Previous literature often adopted quantitative methodology (surveys) to collect both demographical and financial data. A major reason for the survey method was to ensure the right demography was targeted. The accuracy of the demography could be easily verified using data from the World Bank, United Nations, the IMF, and previous literature. The author is also a member of the surveyed respondents' community and culturally affiliated with them. Insider access contributes to the accuracy and quality of the data collected.

According to Nayak and Narayan (2019), data is of utmost importance for any research, and researches are 
predominantly based on primary data. Research methodologies often vary, however, every research is based on good quality data, from which information is extracted. A survey may be described as an inquiry of opinions or experiences of a selected group of people based on a precisely designed series of questions. The questions are preset to extract specific data (demography, preferences, behaviours, etc.) that will answer the research questions. Surveys can be precise and narrow, or they can have more universal, common goals, and psychologists and sociologists frequently employ surveys to analyse behaviour (Nayak \& Narayan, 2019). Since a survey is good for behaviourial analysis, it is useful to investigate the remittance behaviour of the respondents.

The main purpose of survey sampling is to ensure consistent and precise extrapolation to a wider population, often referred to as 'representation' (Baker \& Michel, 2013). A good survey process must be preceded by at least a test sample population, to ensure it is representative (Nayak \& Narayan, 2019). Thus, 15 random respondents were initially surveyed to ensure the efficacy of the survey. This initial survey tested if the questions were easily/fully understood and if the responses were articulate enough to provide the required data. Data collection may be manual or electronic. The survey was conducted using a Google Form (electronic), which automatically downloads responses as an Excel file. Electronic data is superior to manual data because it is cheaper, readily available for analysis and the margin of error is lower. Data and response quality between online and face-to-face surveys are quite similar (Nayak \& Narayan, 2019). Moreover, the survey methodology is effective for this research because the questions were straightforward, required simple answers (an integer or a multiple choice option). The questions and questioning method have also been well tested in previous studies.

\subsection{Ethics and Consent}

Academic research requires ethical standards and consent seeking from respondents before taking their responses. This is to ensure that respondents make an informed decision whether to take part in a survey or not (Roberts \& Allen, 2015). Respondents' consent was sought before they answered the survey. They were informed about the purpose of the research and given the options to either assent or not. Online consent request is very similar to traditional consent/paper presentation (Varnhagen et al., 2005). Respondents' were assured of ethical principles like anonymity, risk, privacy, confidentiality, and autonomy. The consent form was on a different page from the survey. It was concise and precise to ensure respondents do not skip it because of its length. Respondents' data are anonymised to protect their identities, disguise the research's location, and abide by legal privacy requirements. Identity protection is quite important since sensitive and confidential financial information was disclosed.

\subsection{Survey Questions Preparation and Data Collection}

Traditional questionnaires contain either open-ended or structured questions with multiple-choice options (Nayak \& Narayan, 2019. However, several online survey tools provide more options and complexities. These tools include timestamps, IP addresses, email addresses, etc. Google forms possess several options depending on the nature of the survey. These options include Yes/No, True/False, logic-based questions, multiple-choice, short answers, ordinal scale, etc. This article required Yes/No, logic, multiple-choice, and short answers. Questions have already been designed and tested in previous researches and were just adopted for this research. The main drawback of an online survey is the inability to ask respondents leading questions to probe further.

Data is easily collected in online surveys in an Excel file or other desired choices. Google forms already visualise data in different charts before analysis. These charts could be misleading because sometimes, not all respondents' data meet useable standards. Thus, researchers often need to check and clean the data before final analysis and visualisation.

\subsection{Research goals, approach, questions, and hypothesis}

The research investigated how and why the respondents remitted to Nigeria. The major goal of this research was to develop a model that would lay the groundwork for the estimation of the global unofficial remittances to Nigeria. This model would be tested for its general application. The present research aims include:

1. Correlation of respondents' demography with previous literature.

2. Ascertaining the means of remittance.

3. The percentage of income being remitted.

4. Reasons for remittance.

Research approach:

1. Quantitative statistical analysis of the respondents' data in Microsoft Excel.

2. Comparison of data to previous literature.

3. Identification of insights from data analysis.

The analysis should answer the following research questions:

$R Q 1$. Which means of remittance do the respondents favour?

$R Q 2 . \quad W h y$ do they favour this means?

RQ3. How much do the respondents remit back home? 
RQ4. What are the main reasons for remittance?

RQ5. Is this process generalisable across the world?

The following hypotheses were proposed:

H1. Respondents favour peer-to-peer exchanges.

H2. Respondents remit for several reasons.

H3. Unofficial remittance is significant.

H4. The process is globally applicable.

\subsection{Quantitative Analysis}

Quantitative analysis (QA) is a technique that adopts mathematical and statistical modelling, measurements, and research to understand data behaviour. It is used for modelling real-life situations. QA is a statistical method of analysing data to identify patterns, gain insights and make informed decisions. It is a scientific method of using numbers to establish facts. The survey was conducted with a Google Form. The data was collected and analysed in Excel. The analysis required for this research was quite basic (means, ranges, sums, etc.). This is because the research mostly required the financial income and expenses of respondents and comparing the data with previous literature to ascertain demographical accuracy, identify already proven theories and learn new developments. However, deeper statistical analysis would be required should the research be generalisable for a broader range of respondents, across the world.

\section{Discussion}

203 students were surveyed and 183 returned usable data ( $17 \%$ female and $83 \%$ male). $16 \%$ were undergraduates, $82.55 \%$ were Master's students and just 3\% were Ph.D. students. Their average age was 32.6 years, female ( 27 years) and male (33 years). $20 \%$ of the respondents were married (3\% female and $17 \%$ male). All the women and $38 \%$ of the men have their families with them. $95.5 \%$ of the students are employed (16.5\% female, $79 \%$ male).

The respondents had an average monthly income of $€ 908.22$ and the women earned $€ 45$ more than men. The minimum wage in Germany is €9.6/hour (Iamexpat, 2021) and students who work 80 hours/month should earn at least $€ 768$ /month or $€ 9,216$ /annum. However, students earn more because employers often pay higher than the minimum wage, especially for skilled jobs. Thus, the €908 average income is valid. Single room rent varies between $€ 200$ and $€ 400$ per month (Studierendenwerk, 2021), health insurance costs between $€ 35$ to $€ 105$ monthly, and feeding costs between $€ 100$ and $€ 200$ monthly (assuming they all cook).

Assuming a monthly rent of $€ 260$, health insurance of $€ 70$, and feeding of $€ 150$; a student should spend $€ 480$ monthly and have $€ 428$ (€908 - €480) disposable income. $96.5 \%$ of the students $(16.5 \%$ female and $80 \%$ male) remitted to Nigeria. The females remitted just $5 \%$ of their income, while the males remitted $16 \% .92 .5 \%$ of the students use peer-to-peer exchanges and only women used other means of remittance.

\subsection{Remittance, Research Questions, and Hypothesis}

$92.5 \%$ of respondents use peer-to-peer for remittance. This answers RQ1. Peer-to-peer means exchanging Euros for Naira within the student community. This is possible only where everyone is known and mutual trust is established. A student who wants to send money to Nigeria looks for another student who needs money in Germany. The latter would then transfer Naira to the former's Naira account, while the former would transfer Euros to the latter's Euro account. This is beneficial to both parties since the transactions are at no charge and also faster than every other option. These benefits answer RQ2, why a particular means of remittance is favoured. Conversely, peer-to-peer upholds Ambrosius and Cuecuecha's (2016) assertion that links remittances to saving accounts in home countries. Thus, migrants with savings accounts are prime for unofficial remittance. 
Table 1. Respondents' data and demography.

\begin{tabular}{|c|c|c|c|c|c|c|}
\hline & & Female & Male & Total & $\begin{array}{l}\text { Female } \\
(\%)\end{array}$ & $\begin{array}{l}\text { Male } \\
(\%)\end{array}$ \\
\hline Number of Students & & 32 & 151 & 183 & 17 & 83 \\
\hline Average Age & & 27 & 33 & 32.6 & & \\
\hline \multirow[t]{3}{*}{ Education } & \multirow{3}{*}{$\begin{array}{l}\text { Undergraduate } \\
\text { Masters } \\
\mathrm{PhD}\end{array}$} & 9 & 19 & 28 & 5 & 10.5 \\
\hline & & 21 & 128 & 149 & 11.5 & 70 \\
\hline & & 2 & 4 & 6 & 1 & 2 \\
\hline \multirow[t]{2}{*}{ Married } & \multirow{2}{*}{$\begin{array}{l}\text { Yes } \\
\text { No }\end{array}$} & 6 & 31 & 37 & 3 & 17 \\
\hline & & 26 & 120 & 146 & 14 & 66 \\
\hline \multirow[t]{2}{*}{ Married } & \multirow{2}{*}{$\begin{array}{l}\text { With Family } \\
\text { Without } \\
\text { Family }\end{array}$} & 6 & 6 & 12 & 3 & 3 \\
\hline & & 0 & 26 & 26 & 0 & 14 \\
\hline \multirow[t]{2}{*}{ Employment } & \multirow{2}{*}{$\begin{array}{l}\text { Employed } \\
\text { Unemployed }\end{array}$} & 29 & 145 & 174 & 16.1 & 79 \\
\hline & & 3 & 6 & 9 & 1.6 & 3.3 \\
\hline Average income & & $€ 946.1$ & $€ 901$ & $€ 908.22$ & & \\
\hline $\begin{array}{l}\text { Average } \\
\text { income/month }\end{array}$ & & $€ 1,525$ & $€ 1,868.18$ & $€ 1,813.27$ & & \\
\hline Remittance & $\begin{array}{l}\text { Monthly } \\
\text { Quarterly } \\
\text { Biannually } \\
\text { Per request } \\
\text { Sparingly } \\
\text { Never }\end{array}$ & $\begin{array}{r}10 \\
7 \\
5 \\
6 \\
1 \\
3\end{array}$ & $\begin{array}{r}93 \\
42 \\
6 \\
5 \\
0 \\
5\end{array}$ & $\begin{array}{r}103 \\
49 \\
11 \\
11 \\
1 \\
8\end{array}$ & $\begin{array}{l}5.5 \\
3.8 \\
2.7 \\
3.3 \\
0.5 \\
1.6\end{array}$ & $\begin{array}{r}50.8 \\
23 \\
3.3 \\
2.7 \\
\\
2.7\end{array}$ \\
\hline Average Amount Remitted & & $5 \%$ & $16 \%$ & & & \\
\hline \multirow[t]{3}{*}{ Means of Remittance } & \multirow{3}{*}{$\begin{array}{l}\text { International } \\
\text { Money } \\
\text { Transfer } \\
\text { Online } \\
\text { Transfer } \\
\text { Peer-to-peer }\end{array}$} & 4 & 0 & & 2 & 0 \\
\hline & & 3 & 0 & & 1.5 & \\
\hline & & 22 & 146 & & 12.5 & 80 \\
\hline
\end{tabular}

175 of the 183 respondents remit money to Nigeria. They remit at intervals, ranging from monthly to sparingly. Monthly, quarterly, and biannually remittances were easy to calculate. Per request was assigned 5 requests per annum and sparingly was assigned just one-time remittance per annum. Thus, the 175 students remit $€ 199,423.31$ annually or each student remits $€ 95(€ 199,423.31 /(175 * 12))$ monthly or $€ 1152$ annually. This answers RQ3. Furthermore, there were 2,409 Nigerian students (1,970 male and 409 female) in Germany in 2018 (Sahara Reporters, 2018), with an 18\% annual increase. Assuming just a 5\% increase in 2020 and 2021 due to the Covid19 pandemic, there should be about 3,134 Nigerian students in Germany today. Therefore, the total remittance of Nigerian students in Germany is approximately $€ 3,610,635$, assuming similar factors in the research city apply to other cities. 
Table 2. Amounts remitted by the respondents.

\begin{tabular}{|c|c|c|c|c|}
\hline & Female & Male & Total & Annual total \\
\hline Average income & $€ 946.10$ & $€ 901$ & & \\
\hline Students who remit & 29 & 146 & & \\
\hline$\%$ of income remitted & $5 \%$ & $16 \%$ & & \\
\hline Average amount remitted/month & $€ 47.31$ & $€ 144.16$ & & \\
\hline $\begin{array}{l}\text { Monthly remittance } \\
\text { Quarterly } \\
\text { Biannually } \\
\text { Per request } \\
\text { Sparingly }\end{array}$ & $\begin{array}{r}€ 473.05 \\
€ 331.14 \\
€ 236.53 \\
€ 283.83 \\
€ 94.61\end{array}$ & $\begin{array}{r}€ 13,406.88 \\
€ 6,054.72 \\
€ 864.96 \\
€ 720.80\end{array}$ & $\begin{array}{r}€ 13,879.93 \\
€ 6,385.86 \\
€ 1,101.49 \\
€ 1,004.63 \\
€ 94.6\end{array}$ & $\begin{array}{r}\epsilon 166,559.16 \\
\epsilon 25,543.42 \\
\epsilon 2,202.97 \\
\epsilon 5,023.15 \\
\epsilon 94.61\end{array}$ \\
\hline Total annual remittance & & & & $€ 199,423.31$ \\
\hline
\end{tabular}

The reasons for remittances varied and $73 \%$ of the respondents remitted to 'help out family members'. 45\% of this $73 \%$ were females. $13 \%$ (33\% female and 67\% male) of the respondents remitted to repay loans. $23 \%$ (all male) of respondents remit to invest back home. Only 3\% (male) gave out soft loans to family and friends. $3 \%$ of the respondents also remit for religious reasons. This answers RQ4.

Since respondents favour peer-to-peer exchanges, $H 1$ accepted. Respondents remitted for various reasons, $H 2$ is accepted. $92.5 \%$ of respondents use peer-to-peer exchanges, meaning unofficial remittance is significant and $H 3$ is accepted. The logical steps with which the model was developed can be easily replicated and globally applied to any population sample. This makes $H 4$ accepted.

\section{Conclusion}

The data analysis reveals that remittance via unofficial channels is an important subject. This is because the volume of peer-to-peer transactions and the total amount involved is significant. The findings may be summarised as follows:

1. $175(95.7 \%)$ of the 183 respondents remit to Nigeria. Amounts remitted varied, the men remitted thrice as much as the women. The ratio of men to women is $5: 1$.

2. The average age (32.6 years) of the respondents corresponds to Batistaa and Umblijs' (2015) assertion of 33 years. The students should be fully employed professionals in Nigeria, but are studying in Germany. $81.5 \%$ of them are master's students, meaning they already had at least 18 years of schooling in Nigeria (Kindergarten to master level takes 18 to 23 years). Thus, at 25 years, an average educated Nigerian is fully educated and employable. However, Nigeria's $42.5 \%$ youth unemployment (NBS, 2021) is a major reason most of the respondents migrated to Germany as students; to legally access the German job market. The student (visas) route validates Azizi's (2014) assertion that migrants from poor countries often face entry barriers. Most would have been denied working visas and the German language is also another direct entry barrier.

3. $92.5 \%$ of the respondents use peer-to-peer means of remittance. It is free, reliable, and instantaneous. There has been no recorded breach of trust in the last 26 months since the author became aware of the community. Peer-to-peer creates different possibilities for the movement of money. While all the exchanged Naira certainly remains in Nigeria, the corresponding Euros could be domiciled anywhere across the world. Thus, this creates another movement of Euros, since some of the Euro accounts may be domiciled outside Germany.

4. Respondents remit a total of $€ 199,423.31$ or $€ 1,140$ each annually or $€ 95$ each monthly. Each has at least an average of $€ 428$ left after all monthly expenses, from which the $€ 95$ is remitted monthly. Should other German cities be exactly similar, the volume of peer-to-peer remittances could be just over $€ 3,600,000$ annually (from 3,134 Nigerian students). $€ 1,140$ is about half the average amount $(\$ 2,603)$ migrants from developing countries send back home. Thus, $€ 1,140$ annual remittance per student is quite high, as they mostly earn minimum wage while working 20 hours per week.

However, $€ 1,140$ is conservative because most/all students work full-time during the summers and earn 
higher than the minimum wage. Also, there are uncontracted jobs (cleaning, moving men, etc.) students do, that pay instant cash. This cannot be quantified since there is no paperwork. The average monthly income of $€ 908$ is conservative and many of the students probably earn higher and can therefore remit more than $€ 95$ monthly. Thus, an average student remits at least $10.5 \%$ of income.

5. The reasons for remittances were to help out family and friends $(73 \%)$, to repay loans $(13 \%)$, and to invest (23\%). The $73 \%$ who remit to help out their loved ones validate the World Bank's (2006) international discourse assertion that the impact of migration has evolved from, "migration driven by poverty to poverty reduction and development through remittances". The students' reasons for remittances also correspond to Azizi's (2014) and Batistaa and Umblijs (2015) findings - altruism, loan repayments, and investments. The number of students remitting to self-insure is significant, considering the low incomes. This also supports Batistaa and Umblijs (2015) assertion that students were risk-takers. All married male students with families back in Nigeria remit monthly, and higher than all the other students.

\subsection{Limitations}

The survey was limited to only students in one city. This was the basis for the assumption made across Germany. These assumptions include:

1. Students have closely similar financial situations across the country, though some cities are more expensive than others. It is possible that the average monthly disposable income after all deductions remains around $€ 480$ because the expensive cities also have higher minimum wages.

2. Most students use peer-to-peer services since they all belong to their respective cities' communities. Transactions incur no charges and mutual trust is well established owing to communal and cultural ties in a foreign country.

3. This study/methodology may be replicated and generalised among Nigerian students across the world, but not expatriates. Thus, the above assumptions would not be applicable to Nigerian expatriates across the world. Expatriates are unlikely to belong to similar communities as students, and they earn higher than students. Nonetheless, the remittances practices of other Nigerian migrants should be investigated.

These limitations need further clarity to ensure that the assumptions above are valid or close enough. Otherwise, the model for future research would have been built on inaccurate information. Thus, this methodology should be applied to other German cities first before doing research across different countries.

\subsection{Implications}

The findings show that the banking/financial sector is losing out significantly to the unofficial remittance channels. The stakeholders should be thinking of ways to compete with the unofficial market by offering attractive, better, and cheaper services. The charges or marginal profits that ought to go to the Nigerian market go to other countries where Nigerians have domiciled Euro accounts.

\subsection{Future research}

Future research may build on these findings and attempt to develop a model for fully employed Nigerian migrants across the world. The research must determine the number of migrants that use unofficial remittance services and how much they remit. This information can be used to determine the total amount of unofficial remittances as well as the total amount of all remittances combined. This would paint a clearer picture of the FDI-remittances dichotomy.

\section{References}

Ambrosius, C \& Cuecuecha, A (2016) Remittances and the Use of Formal and Informal Financial Services, World Development, 77 (2), 80-98, doi.org/10.1016/j.worlddev.2015.08.010.

Baker, R \& Michel, J. B. (2013). Summary Report of the AAPOR Task Force on Non-probability Sampling. Journal of Survey Statistics and Methodology, 1 (2), 90-143, DOI: 10.1093/jssam/smt008.

Batista, C. \& Umblijs, J. (2016) Do migrants send remittances as a way of self-insurance? Oxford Economic Papers, 68(1), 108-130, doi: 10.1093/oep/gpv049.

Azizi, S. (2019) 'Why Do Migrants Remit?', World Economy, 42 (2), 429-452, doi.org/10.1111/twec.12681.

Central Bank of Nigeria (2021). Naira 4 Dollar Scheme. [Online] Available: cbn.gov.ng/Out/2021/CCD/naira4dollar.pdf.

Clark, A. (2006). Real Life Methods Working Papers: Anonymising Research Data [Internet]. ESRC National Centre for Research Methods, University of Manchester. [Online] Available: Anonymising Research Data

Ioannidis, J. P. A., Fanelli, D., 'Dunne, D. D. \& Goodman, S. N. (2015). Meta-research: Evaluation and Improvement of Research Methods and Practices'. PLoS Biol. 13(10), 1-7.

Khanal, K., \& Todorova, Z. (2021). Remittances and Households within Neoliberalism: A “Triple Movement." Journal of Economic Issues (Taylor \& Francis Ltd), 55(2), 461-468. 
doi.org/10.1080/00213624.2021.1909345.

Mintchev, V., \& Boshnakov, V. (2021). Return Migration and Remittances: Recent Empirical Evidence for Bulgaria. Economic Studies, 30(3), 56-75.

Nigerian Bureau of Statistics, NBS (2021). Youth Unemployment in Nigeria. [Online] Available: nigerianstat.gov.ng/elibrary?queries=labour (October 18, 2021).

Nayak, M. S. D. P., \& Narayan, K. A. (2019). Strengths and Weaknesses of Online Surveys. IOSR Journal Of Humanities And Social Science (IOSR-JHSS), 24 (5), 31-38. DOI: 10.9790/0837-2405053138 31.

Onu, E. (2020), World's Outlier on Remittances Has Currency Woes to Blame. Bloomberg. [Online] Available: bloombergquint.com/global-economics/world-s-outlier-on-remittances-has-its-currency-woes-to-blame (November 26, 2020).

Nwokoye, E. S., Igbanugo, C. I., \& Dimnwobi, S. K. (2020). International Migrant Remittances and Labour Force Participation in Nigeria. African Development Review, 32(2), 125-137. doi.org/10.1111/1467-8268.12421.

Ratha, D., De, S., Kim, E. J., Plaza, S., Seshan, G., \& Yameogo, N. D., (2019). Data release: Remittances to lowand MIDDLE-INCOME countries on track to Reach \$551 billion in 2019 And \$597 billion by 2021. [Online] Available: worldbank.org/peoplemove/data-release-remittances-low-and-middle-income-countries-trackreach-551-billion-2019 (October 16, 2019)

Roberts, L.D. \& Allen, P. J. (2015). Exploring Ethical Issues Associated With Using Online Surveys in Educational Research. Educational Research and Evaluation, 21(2), 95-108. doi.org/10.1080/13803611.2015.1024421.

Sahara Reporters, (2019). Nigerians ranked fifth among African students in Germany. [Online] Available: nigerianstudentsingermany (June 28, 2019)

Statista, (2021), The World's Top Remittance Recipients. [Online] Available: statista.com/chart/20166/top-10remittance-receiving-countries/ (May 14, 2021)

Statista, (2021), African countries with the highest Gross Domestic Product (GDP) in 2021. [Online] Available: statista.com/statistics/1120999/gdp-of-african-countries-by-country/ (September 20, 2021)

Statista, (2021), Value of remittance inflows to Nigeria from 2010 to 2020 (in billion U.S. dollars) [Graph].. remittance-inflows-to-nigeria (May 12, 2021)

Studierendenwerk, (2021), Wohnanlage Campus. Wohnanlage Campus | Studierendenwerk. [Online] Available: studentenwerke.de/ (April 1, 2021)

Sunam, R. \& McCarthy, J.F. (2016). "Reconsidering the Links between poverty International Labor migration, and Agrarian Change: Critical Insights from Nepal." The Journal of Peasant Studies 43 (1): 39-63. dx.doi.org/10.1080/03066150.2015.1041520.

United Nations, (2021). International data. Migration data portal. [Online] Available: migrationdataportal.org/ (January 20, 2021)

United Nations, (2021), Remittances. Migration data portal. [Online] Available: migrationdataportal.org/ (June 3, 2021)

Varrella, S. (2021), Nigeria: Share of international migrants 2020. Statista. [Online] Available: migrantstock (November 1, 2021)

Varrella, S., (2021), Nigeria: Population 1950-2021. Statista.[Online] Available: nigeriapopulation (September 28, 2021)

Varnhagen CK, Gushta M, Daniels J, Peters TC, Parmar N, Law D, Hirsch R, Takach BS, \& Johnson T. (2005). How informed is online informed consent? Ethics \& Behavior, 15(1), 37-48.

Wedia, (n.d.), Salary, payslips \& minimum wage in Germany. [Online] Available: IamExpat

World Bank. (2011) Migration and Remittances Factbook 2011, Washington, DC, World Bank Publications.

World Bank, (2006), Global Economic Prospects: Economic Implications of Remittances and Migration. Washington, DC: International Bank for Reconstruction and Development.

World Bank, (2019), Migration and Remittances. [Online] Available: WorldBank (September 26, 2019)

World Bank, (2020), Migration and Development Brief 33. [Online] Available: KNOMAD.

World Bank. (2021), Migration and remittances data. [Online] Available: migrationandremittances (November $16,2017)$

World Bank, (2021), Defying predictions, remittance flows remain strong during covid-19 crisis. [Online] Available: worldbank.org/en/news/press-release/2021/05/12 (May 12, 2021) 